\title{
Equipment Maintenance Management in Manufacturing Companies: An Application for Total Maintenance Costs Model
}

Emre BILGIN SARI ${ }^{1}$

\begin{tabular}{ccc}
\hline $\begin{array}{c}\text { Geliş Tarihi/ Received } \\
28 / 11 / 2018\end{array}$ & Kabul Tarihi/ Accepted & Yayın Tarihi/ Published \\
23/03/2020 & $15 / 04 / 2020$ \\
\hline Citation/Atıf: Bilgin, Sarı, E., (2020), Equipment Maintenance Management in Manufacturing \\
Companies: An Application for Total Maintenance Costs Model, Atatürk Üniversitesi İktisadi ve \\
Idari Bilimler Dergisi, 34(2): 335-350, DOI: 10.10000/atauniiibd.000000 \\
\hline
\end{tabular}

Abstract: In production facilities, uninterrupted operations depend on the equipment's ability to perform without any problem. Therefore, maintenance activities are an issue that must be managed within the goals of production companies. Effective management of equipment maintenance directly affects operating performance. On the other hand, maintenance operations involve costly activities. The cost dimension is a critical consideration about maintenance unless the cost-benefit analysis is done correctly by the enterprises. However, there could be more costly situations when the problems are revealed by inadequate maintenance. In this study, total maintenance costs were examined to manage equipment maintenance. The maintenance activities of a company were analyzed the total maintenance costs model was applied.

Keywords: Equipment Maintenance Management, Overall Equipment Efficiency, Total Productive Maintenance, Total Maintenance Cost

\section{Üretim İşletmelerinde Ekipman Bakımı Yönetimi: Toplam Bakım Maliyetleri Modeli Uygulamasi}

Öz: Üretim işletmelerinde, operasyonların kesintisiz olarak sürdürülebilmesi ekipmanların çalışmalarını sorunsuz bir şekilde yerine getirebilmesine bağlıdır. Bu nedenle yapılan bakım faaliyetleri, üretim ișletmelerinin hedefleri içerisinde yönetilmesi gereken bir konudur. Ekipman bakımının iyi yönetilmesi, işletme performansını doğrudan etkilemektedir. Diğer taraftan bakım işlemleri, maliyet gerektiren faaliyetleri içermektedir ve işletmeler tarafindan fayda maliyet analizi doğru yapılmadığı sürece maliyet boyutu dikkate alınmaktadır. Ancak yetersiz bakımın neden olduğu problemler ortaya çıkarıldı̆̆ında, daha büyük maliyetler olduğu görülmektedir. Bu çalışmada ekipman bakımının yönetilmesi için toplam bakım maliyetleri üzerine çalışılmaktadır. Bir firmanın bakım faaliyetleri analiz edilerek, yetersiz bakımın neden olduğu durumlar ile toplam bakım maliyetleri modeli uygulanmaktadır.

Anahtar Kelimeler: Ekipman Bakımı Yönetimi, Toplam Ekipman Etikinliği, Toplam Üretken Bakım, Toplam Bakım Maliyeti

\footnotetext{
${ }^{1}$ Arş. Gör. Dr., Dokuz Eylül Üniversitesi, İktisadi ve İdari Bilimler Fakültesi, İşletme Bölümü, https://orcid.org/0000-0001-5110-1918
} 
Equipment Maintenance Management in Manufacturing Companies: An Application for Total Maintenance Costs Model

\section{GENIŞLETILMIŞ ÖZET}

Arkaplan: İşletmelerin temel fonksiyonlarından birisi olan üretim işlemlerinin etkin ve etkili şekilde sürdürülebilmesi çağdaş endüstriyel sistemlerin ayrılmaz parçası olarak ekipmanların yönetimini gerektirmektedir. Üretim işletmelerinin faaliyetlerini kesintisiz bir şekilde sürdürebilmeleri ekipman kullanılabilirliği ile ilgilidir. Ekipman performansının yönetilmesi ise bakım işlemlerinin etkin bir şekilde planlanması, uygulanması ve kontrol edilmesi ile gerçekleşmektedir. Diğer taraftan, bakım harcamaları, makine ve teçhizat yatırımları yoğun olan kurulușlarda ișletme bütçesinin büyük bir bölümünü teşkil etmekte ve bu tür kuruluşlarda bakım işlemlerinin performansının takip edilmesi önemli bir yönetim konusu olmaktadır.

Çalışmanın Amacı: Çalışmanın amacı, ekipman bakımı yönetimine dikkat çekmektir. Toplam bakım maliyetleri modeli ile bakım faaliyetlerinin etkin kullanımını ortaya çıkarmaktadır. Çalışma bir üretim işletmesinin arıza analizi yapılması ile başlayıp yetersiz bakım maliyetlerinin ortaya çıkarılmasında kullanılan geleneksel bakım maliyeti modeline alternatif bakım maliyeti modeli geliştirilmesi ile devam etmektedir. $\mathrm{Bu}$ çalışmaya konu olan problem işletmelerin sıklıkla karşılaştıkları ancak çoğunlukla göz ardı ettikleri bir durum üzerindedir.

Yöntem: Bakım maliyetlerinin yönetimi konusunda yapılan çalışmalar Önleyici bakım (PM / Preventive Maintenance) ile Düzeltici bakım (CM / Corrective Maintenance) faaliyetleri üzerinde durmaktadır. Toplam bakım maliyetleri modeli, Toplam bakım maliyeti, yetersiz yapılan ekipman bakımının, işletmelerde neden olduğu maddi kayıpların ortaya çıkarılması ile ilişkilidir. Yapılan hesaplamalarda, bakım faaliyetleri ile yapılan tamir ve yenileme maliyetleri yanında bakım işlemi boyunca üretim ve işçilik kaybı da dikkate alınmaktadır. Toplam bakım maliyeti modelinde (Model 1), geleneksel olarak ele alınan maliyetler düzeltici bakım ve önleyici bakım maliyetlerinin toplanması ile hesaplanmaktadır. Burada düzeltici bakım maliyetleri, ortaya çıkan arıza sonucu tamir maliyeti ile tamir süresi boyunca makinenin çalışmadığı dönemde yaşanan üretim kaybı ve işçilik kayıplarının toplanması ile bulunmaktadır. Önleyici bakım maliyetleri ise bakım gerçekleştirilirken karşılaşılan yenileme maliyetleri ile yenileme süresi boyunca makinenin çalışmadığı dönemde yaşanan üretim kaybı ve işçilik kayıplarının toplanması ile elde edilmektedir. Modelde beklenen toplam bakım maliyeti değeri bir göstergeye dönüştürülmek istendiğinde birim zaman başına maliyet olarak (Cost per Unit Time / CPUT) değeri hesaplanmaktadır. Toplam bakım maliyeti modelinde verilen değerlere ek olarak alternatif bakım maliyeti modelinde (Model 2) iki tür arıza durumu oluştuğu varsayılmaktadır. Düzeltici bakımın yapılması gereken arıza durumları olarak $\mathrm{FC}_{1}$ arıza olduğunda makine hemen durdurulmakta ve düzeltici bakım gerçekleştirilmektedir. $\mathrm{FC}_{2}$ arıza meydana geldiğinde fark edilmeden işleme devam edilmekte, ancak üretim sürecinde kayma yaşanmaktadır. Burada düzeltici bakım maliyetleri, iki farkı ı durum için gerçekleştirilmektedir ve toplam bakım maliyetleri Model 2'de 
değiş̧kenlik göstermektedir. Bu değişime bağlı olarak birim zaman başına maliyet olan (Cost per Unit Time / CPUT) değeri de iki model arasında kıyaslama yapılabilmesine imkan tanıyan bir gösterge olarak ele alınmaktadır.

Sonuç ve Değerlendirme: Bu çalışmada, bir işletmenin arıza takviminde yer alan ekipman duruşları için toplam bakım maliyetleri modeli ele alınmıştır. $\mathrm{Bu}$ maliyet verilerinden hareketle incelenen bakım maliyeti modeli üzerinde 1skartayı göz önde bulunduran modelin yüksek birim maliyet ile sonuç vermesi bakım faaliyetlerinin doğru yürütülmesi gerektiğine bir kez daha dikkat çekmek için betimleyici olmuştur. İşletmeler için düşük bakımın maliyeti düşünülürken üretim kaybı işçilik kaybı yanında 1skarta maliyetleri de ele alınmıştır ve dakikada 19 TL maliyet etkisinin yıllık yaklaşı 6.000.000 TL'lik bir etkisi olacağı bunun da işletme için bakıma yönelik yatırımlarından daha fazla olduğunu göstermiştir. Burada bakım faaliyetlerinin maliyetli olduğu verilerine karşılık bakım yetersizliğinin daha maliyetli olacağı belirtilmiştir. Ayrıca işletmelerin bakım sistemlerini iyileştirmeleri ve bakım performanslarını geliştirmeleri ile birlikte yetersiz bakımın etkilerinden uzaklaşan ve daha da iyiye giden bir sistem yaratmaları mümkün olacaktır.

\section{INTRODUCTION}

The management of the equipment is crucial for efficient and effective maintenance of production processes. Maintenance activities is an integral part of the modern industrial systems. Manufacturing philosophies such as Just-inTime (JIT) and lean are supporting the improvement of equipment utilization in order to produce at low cost, high quality and faster than. Companies have learned that they cannot achieve their goals when they do not take time to maintain their equipment (Aspinwall, \& Elgharib, 2013: 688). Total Productive Maintenance (TPM) system has emerged as a result of the efforts carried out in order to establish a systematic structure for the need for equipment maintenance (Willmott, \& McCarthy, 2001:10). TPM is a human-oriented method based on teamwork and requires managerial skills rather than towards technology and TPM is serving for achieving world class Overall Equipment Efficiency (OEE) performance (Kulkarni, \& Dabade, 2013: 27 - 28; Willmott, \& McCarthy, 2001: 4 - 5). Companies, with acceptance of the maintenance system improve quality, overall performance, operational efficiency, cost effectiveness, and these are providing the firms competitive advantage and long-term profitability (Alsyouf, 2006: 133 - 134; Maletic et al., 2014: 442). On the other hand, maintenance costs constitute the major part of the operating budget in the enterprises which are heavily invested in machinery and equipment. So on, the monitoring the performance of maintenance operations becomes an important management issue in these kind of companies (Tsang et al., 1999: 692).

In the literature, the effects of maintenance activities on production performance and operating profitability are examined in different aspects (Carter, 2001; Kutucuoglu, et al., 2001; Alsyouf, 2007, Maletic, et al., 2014; Azizi, 2015; 
Equipment Maintenance Management in Manufacturing Companies: An Application for Total Maintenance Costs Model

Al-Najjar, \& Algabroun, 2018). The maintenance practices and the positive effects on the production efficiency and the improvement in the operational performance are the subject of these researches. As a common aspect of these studies, it is also explained that, maintenance management plays a critical role in sustaining the activities of businesses. Seeing that the maintenance management from a conventional view, maintenance activities can be perceived as an inevitable source of cost. However, when the effects of maintenance activities on operating profitability are examined in detail, the positive contribution of maintenance management to production efficiency is revealed. Furthermore, by using effective maintenance policies, it is appeared that the failures can be reduced to the minimum level and the defect rejections can be eliminated. These are leading various savings and results in operating profitability (Alsyouf, 2007: 71).

In this study, which is conducted to examine equipment maintenance activities in enterprises, the total maintenance costs model is emphasized. Firstly, the management of equipment maintenance is explained and the issues of maintenance in the fields of production, maintenance, investment and engineering are examined. Then maintenance costs are discussed and calculated. The total cost of maintenance is modelled by considering the traditionally calculated maintenance costs and the alternative costs. In the numerical implementation part of the study, the calculation of the total maintenance costs by using the data obtained from a manufacturing enterprise is done by two different methods and the difference is compared. Alternatively, the cost value, which evaluates scrap costs, is considered as a subject for the evaluation of maintenance performance.

\section{EQUIPMENT MAINTENANCE MANAGEMENT}

The problems experienced in the equipment affect the production costs, therefore effective and efficient maintenance management becomes an indispensable necessity for production success. The occurrence of unexpected failures in the production area disrupts the production flow and causes losses. The regular and continuous operation of a facility, its profitability and efficiency depend on the working of maintenance system. The efficiency of equipment maintenance systems is crucial to the success of companies and affects the main system performance. Parida and Kumar (2006) emphasize the importance of measuring the performance of the system and remark the reduction of equipment maintenance and repair costs. Therefore, the management of equipment maintenance can be defined as a long-term strategic planning. Furthermore, mechanization and automation has increased the amount of capital used for production equipment. These systems deteriorate over time, the great investment is reevaluated, and the importance of equipment maintenance management come into consideration more associable (Wang, 2002: 469; Dekker, 1996: 229). 
Jardine and Buzacott (1985) classified equipment maintenance activities as two main categories: corrective maintenance and preventive maintenance. Preventive Maintenance (PM) refers to all system-operated activities to keep the component under certain conditions by systematic monitoring, detection (Wang and Pham, 1996: 425 - 426). The PM is used to control equipment breakdowns and failures. Corrective maintenance (CM) refers to all activities that occur to bring the part to a specific position, as a result of failures and the system breakdowns (Wang and Pham, 1996: 425). The CM is used to return the failed equipment to the operating state again.

Equipment maintenance management is classified as operations made by manufacturing, maintenance, investment \& engineering. While Autonomous Maintenance (AM) is made by manufacturing function, maintenance department manages Breakdown Maintenance (BM), Time-based Maintenance (TBM), and Condition-based Maintenance (CBM). Maintenance Prevention activities are listed in the maintenance activities of Investment and Engineering function (Sar1, 2018: 78 - 80). These maintenance operations, which are applied in different times and conditions, also vary by the departments in which they are carried out. Figure 1 exhibits the maintenance activities according to the business units and their root plan. And then, Table 1 is prepared for detailing maintenance activities.

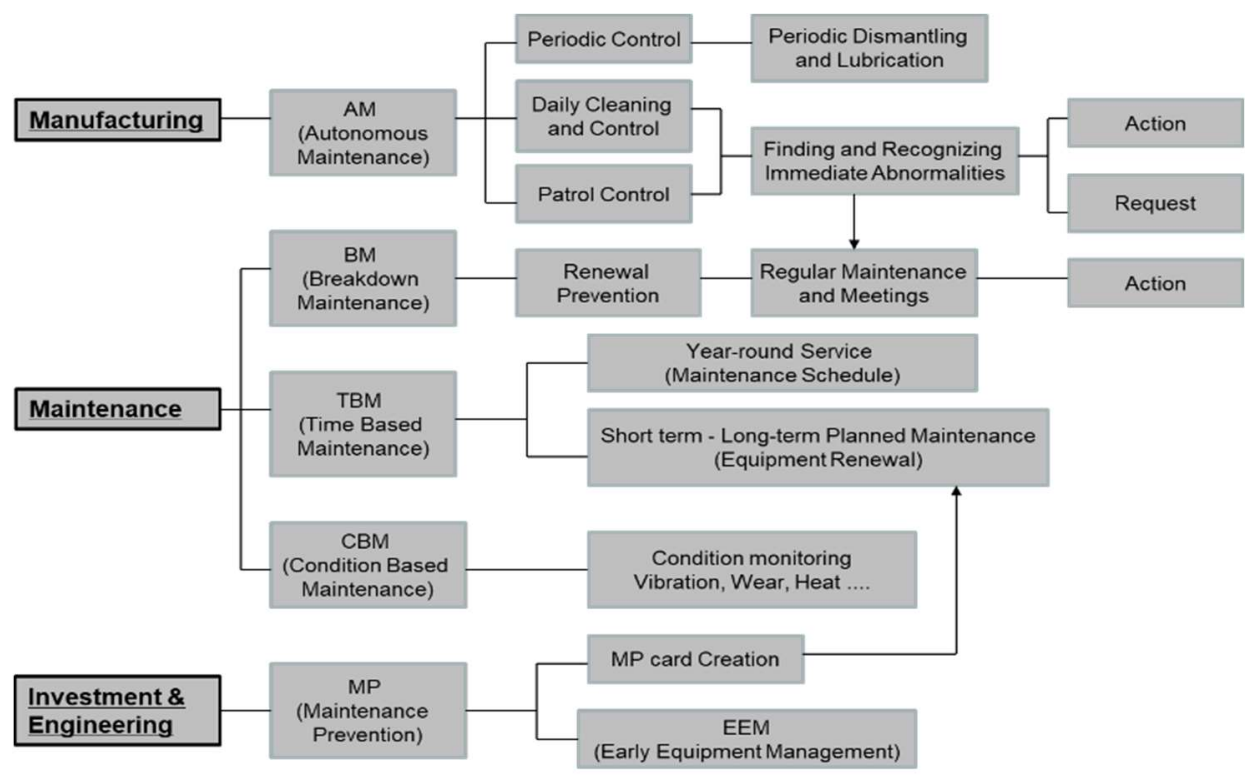

Ref: (Sar1, 2018: 79)

Figure 1: Maintenance Activities and Action Plan 
Equipment Maintenance Management in Manufacturing Companies: An Application for Total Maintenance Costs Model

Table 1: Maintenance Activities

\begin{tabular}{|c|c|c|}
\hline $\begin{array}{c}\text { Maintenance } \\
\text { Activity }\end{array}$ & Definition & Implementation Subject \\
\hline $\begin{array}{l}\text { Autonomous } \\
\text { Maintenance } \\
\text { (AM): }\end{array}$ & $\begin{array}{l}\text { The basic maintenance } \\
\text { standards which are } \\
\text { followed and managed by } \\
\text { the operators with the } \\
\text { support of maintenance } \\
\text { personnel is called AM } \\
\text { (Azizi, 2015: 187). }\end{array}$ & $\begin{array}{l}\text { AM includes the tasks that the operators receive } \\
\text { in the maintenance of their equipment, } \\
\text { independent of the maintenance department. } \\
\text { Daily checks, lubrication, part replacement (v- } \\
\text { belt, filter, tailstock, etc.), simple repairs, } \\
\text { reporting abnormal conditions are the main AM } \\
\text { activities. }\end{array}$ \\
\hline $\begin{array}{l}\text { Breakdown } \\
\text { Maintenance } \\
\text { (BM): }\end{array}$ & 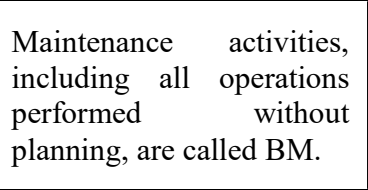 & $\begin{array}{l}\text { The concept of crisis maintenance is also covered } \\
\text { by the BM. Crisis maintenance is defined as } \\
\text { maintenance that occurs when a failure while } \\
\text { (internal and / or external) disruption in customer } \\
\text { shipment (Mahadevan, 2015: 621). }\end{array}$ \\
\hline $\begin{array}{l}\text { Time-Based } \\
\text { Maintenance } \\
\text { (TBM): }\end{array}$ & $\begin{array}{l}\text { All scheduled maintenance } \\
\text { activities are called TBM } \\
\text { to avoid any future } \\
\text { problems. }\end{array}$ & $\begin{array}{l}\text { The risk of failure is reduced when the machines } \\
\text { are operated regularly and applied to the design } \\
\text { standards. Therefore, based on the design } \\
\text { information and operating conditions of the } \\
\text { equipment, the TBM system is established to be } \\
\text { implemented at certain intervals (Ahmad, \& } \\
\text { Kamaruddin, 2012: 137). }\end{array}$ \\
\hline $\begin{array}{l}\text { Condition- } \\
\text { Based } \\
\text { Maintenance } \\
\text { (CBM): }\end{array}$ & $\begin{array}{l}\text { It is called the CBM for the } \\
\text { maintenance system which } \\
\text { is tried to obtain } \\
\text { information about the } \\
\text { condition of the equipment } \\
\text { by observing the working } \\
\text { patterns of the equipment. }\end{array}$ & $\begin{array}{l}\mathrm{CBM} \text { is carried out without waiting for } \\
\text { scheduled maintenance time when it is felt that } \\
\text { the need for maintenance (Ahmad, \& } \\
\text { Kamaruddin, 2012: 140). }\end{array}$ \\
\hline $\begin{array}{l}\text { Maintenance } \\
\text { Prevention } \\
\text { (MP): }\end{array}$ & \multicolumn{2}{|c|}{$\begin{array}{l}\text { MP, which means maintenance preventive works, has a high degree of } \\
\text { reliability, maintenance availability, economy and new technologies related to } \\
\text { maintenance costs and deterioration losses during the planning and construction } \\
\text { of equipment that are the activities carried out to implement interoperability } \\
\text { and flexibility (Thun, 2006: 169). }\end{array}$} \\
\hline
\end{tabular}

Autonomous maintenance activities carried out by the manufacturing function include maintenance operations that can be passed from the maintenance team to the operator. The BM, TBM and CBM works carried out by the maintenance department aim to establish a planned maintenance system by reducing the number of unexpected maintenance. The maintenance and prevention works managed by the Investment and Engineering unit are part of the Early Equipment Management. These studies which dealt with by the various departments within the enterprise are the subject of equipment maintenance management. And the costs of these activities are examined under the head of 
maintenance costs. Furthermore, lack of them are the subject of total maintenance costs.

\section{TOTAL MAINTENANCE COST MODEL}

Maintenance costs are quite remarkable in the industry. According to Maggard and Rhyne (1992), maintenance costs can reach $10 \%$ to $40 \%$ of the product cost. According to Coetzee (2004), this ratio should be between $15 \%$ and $50 \%$. Bevilacqua and Braglia (2000) suggested that this rate is around 15\% to $70 \%$ of the total production costs. Based on these considerations, it can be said that maintenance and repair costs correspond to at least $15 \%$ of the total production costs (Salonen, and Deleryd, 2011: 64). Cost for maintenance should be considered as an investment rather than the cost. According to Swanson (2001: 237), companies have to invest in maintenance for achieving world-class performance standards such as high quality, high customer satisfaction, low production costs and on time production.

Wireman (2004: 4 - 5) argues that one-third of maintenance and repair expenditures are made unnecessarily for poor planning, overtime costs, and low preventive maintenance. Such losses cause an increase in production costs. Also, breakdowns in production systems can create great losses. Time and volume lose can cause customer dissatisfaction by creating a bad image in the external environment. From another perspective, Ahlmann (2002) claimed that cost of maintenance can be divide to three part like that $55 \%$ are direct and $24 \%$ are indirect while $21 \%$ are unrealizable income.

Studies on the management of maintenance costs focus on Preventive Maintenance (PM) and Corrective Maintenance (CM) activities. PM activities, which correspond to increasing failure rates, require additional costs and are considered to be meaningful when PM costs are less than the reduction in CM costs. Various models have been developed in the literature to determine the optimal value of PM activities (Sherif and Smith, 1976; Jardine and Buzacott, 1985; Gits, 1986; Thomas, 1986; Valdes and Feldman, 1989; Cho and Parlar, 1991; Pintelton and Gelders, 1992; Dekker et al., 1997; Scarf, 1997). The basic modeling of maintenance costs is to classify these costs as direct and indirect costs. Direct costs, such as labor, spare parts, are directly related to maintenance and repair costs are counted. The indirect costs (due to material defects) are regeneration of lost production costs such as those due to insufficient quality.

Total maintenance costs are associated with the detection of financial losses caused by insufficient equipment maintenance. In the calculations, maintenance and repair costs are taken into consideration throughout the maintenance process. Table 1 provides a description of the impressions in the total maintenance cost model, which was adapted from Pandey et al. (2010). 
Equipment Maintenance Management in Manufacturing Companies: An Application for Total Maintenance Costs Model

Table 1: Total Maintenance Cost Model Notations

\begin{tabular}{|c|c|c|c|}
\hline MTTR & $=$ Mean Time to Repair & $P\left(F C_{1}\right)$ & $\begin{array}{l}=\text { Probability of Failure } \\
\text { Condition I }\end{array}$ \\
\hline$M T B F$ & $\begin{array}{l}=\text { Mean Time Between } \\
\text { Failures }\end{array}$ & $P\left(F C_{2}\right)$ & $\begin{array}{l}=\text { Probability of Failure } \\
\text { Condition II }\end{array}$ \\
\hline$N_{C M}$ & $=$ The Number of CM & $E\left(C_{P M}\right)_{M 1}$ & $\begin{array}{l}=\text { Expected PM Cost for } \\
\text { Model M1 }\end{array}$ \\
\hline$N_{P M}$ & $=$ The Number of PM & $E\left(C_{P M}\right)_{M 2}$ & $\begin{array}{l}=\text { Expected PM Cost for } \\
\text { Model M2 }\end{array}$ \\
\hline$P R$ & $\begin{array}{l}=\text { Production Rate by unit } \\
\text { time }\end{array}$ & $E\left(C_{C M}\right)_{M 1}$ & $\begin{array}{l}=\text { Expected CM Cost for } \\
\text { Model M1 }\end{array}$ \\
\hline$C_{l p}$ & $\begin{array}{l}=\text { Cost of Lost Production } \\
\text { by unit }\end{array}$ & $E\left(C_{C M}\right)_{M 2}$ & $\begin{array}{l}=\text { Expected CM Cost for } \\
\text { Model M2 }\end{array}$ \\
\hline$L C$ & $=$ Labor Cost by unit & $E\left(C_{C M}\right)_{F C_{1}}$ & $\begin{array}{l}=\text { Expected CM Cost in } \\
\text { Case of Failure I }\end{array}$ \\
\hline$T$ & $\begin{array}{l}=\text { The Planning Period in } \\
\text { which the Analysis was } \\
\text { made }\end{array}$ & $E\left(C_{C M}\right)_{F C_{2}}$ & $\begin{array}{l}=\text { Expected CM Cost in } \\
\text { Case of Failure II }\end{array}$ \\
\hline$T^{*}$ & $=$ Maintenance Interval & $E\left(C_{r e j}\right)$ & $=$ Expected Rejection Cost \\
\hline$C_{\text {rep }}$ & $=$ Repair Cost per Fault & $E\left(C_{f}\right)_{M 1}$ & $\begin{array}{l}=\text { Expected Total Cost for } \\
\text { Model M1 }\end{array}$ \\
\hline$C_{r e j}$ & $\begin{array}{l}=\text { Cost of Rejecting Units } \\
\text { per Job }\end{array}$ & $E\left(C_{f}\right)_{M 2}$ & $\begin{array}{l}\text { = Expected Total Cost for } \\
\text { Model M2 }\end{array}$ \\
\hline$C_{\text {res }}$ & $\begin{array}{l}=\text { Replacement Cost per } \\
\text { Fault }\end{array}$ & $C P U T_{M 1}$ & $\begin{array}{l}=\text { Cost Per Unit Time for } \\
\text { Model M1 }\end{array}$ \\
\hline$N_{\text {defect }}$ & $\begin{array}{l}=\text { Number of defected } \\
\text { products }\end{array}$ & $C P U T_{M 2}$ & $\begin{array}{l}=\text { Cost Per Unit Time for } \\
\text { Model M2 }\end{array}$ \\
\hline
\end{tabular}

In the total maintenance cost model (Model 1), the cost traditionally considered are calculated by the summation of CM and PM costs. CM cost are determined by the cost of repair as a result of the failure and the loss of production and loss of labor during the period of inactivity during the repair period. PM cost are obtained through the renewal cost encountered during maintenance and the loss of production and loss of labor during the period of non-operation during the renovation period. When the total cost of maintenance is expected to be converted into an indicator, the cost per unit time (CPUT) is calculated.

Corrective Maintenance Cost:

$E\left(C_{C M}\right)_{M 1}=\operatorname{MTTR}_{C M} x\left[P R \times C_{L P}+L C\right]+\overline{C_{r e p}}$

Preventive Maintenance Cost:

$E\left(C_{P M}\right)_{M 1}=\operatorname{MTTR}_{P M} x\left[P R \times C_{L P}+L C\right]+\overline{C_{r e s}}$ 
TOTAL MAINTENANCE COST:

$$
\begin{gathered}
E\left(C_{f}\right)_{M 1}=\left\{E\left[N_{C M}\right] x E\left(C_{C M}\right)_{M 1}\right\}+\left\{\left[N_{P M}\right] x E\left(C_{P M}\right)_{M 1}\right\} \\
C P U T_{M 1}=\frac{E\left(C_{f}\right)_{M 1}}{T^{*}} \\
T^{*}=\frac{T}{M T B F}
\end{gathered}
$$

In addition to the values given in the total maintenance cost model, it is assumed that there are two types of failure conditions as an alternative maintenance cost model (Model 2). These failures are named as $\mathrm{FC}_{1}$ and $\mathrm{FC}_{2} . \mathrm{CM}$ requires $\mathrm{FC}_{1}$ as failure condition, the machine is stopped immediately and the corrective maintenance is performed. When $\mathrm{FC}_{2}$ failure occurs, processing is continued unnoticed but there is a shift in the production process and faulty production is composed. The probability of occurrence of $\mathrm{FC}_{1}$ and $\mathrm{FC}_{2}$ failures is 1.

Corrective Maintenance Cost: $P\left(F C_{1}\right)+P\left(F C_{2}\right)=1$

$$
\begin{aligned}
& E\left(C_{C M}\right)_{F C_{1}}=M T T R_{C M} x\left[P R \times C_{L P}+L C\right]+\overline{C_{r e p}} \\
& E\left(C_{C M}\right)_{F C_{2}}=E\left(C_{r e j}\right)+M T T R_{C M} x\left[P R x C_{L P}+L C\right]+\overline{C_{r e p}} \\
& E\left(C_{r e j}\right)=C_{r e j} x E\left(N_{\text {defect }}\right)
\end{aligned}
$$

Preventive Maintenance Cost:

$$
E\left(C_{P M}\right)=M T T R_{P M} x\left[P R \times C_{L P}+L C\right]+\overline{C_{r e s}}
$$

TOTAL MAINTENANCE COST:

$$
\begin{aligned}
E\left(C_{f}\right)_{M 2}= & E\left(N_{C M}\right) \times\left\{\left[E\left(C_{C M}\right)_{F C_{1}} \times P\left(F C_{1}\right)\right]+\left[E\left(C_{C M}\right)_{F C_{2}} \times P\left(F C_{2}\right)\right]\right\} \\
& +\left\{\left(N_{P M}\right) \times E\left(C_{P M}\right)\right\} \\
C P U T_{M 2}= & \frac{E\left(C_{f}\right)_{M 2}}{T^{*}}
\end{aligned}
$$

Corrective maintenance costs are carried out for two different conditions and the total maintenance costs vary in Model 2. Depending on this difference, the cost per unit time (CPUT) is considered as an indicator that allows comparison between the two models. To explain this difference an industry application is given in following section.

\section{CASE STUDY IMPLEMENTATION}

As an automotive supplier; the implementation company manufactures fasteners for the automotive industry. The company is among the leading 
Equipment Maintenance Management in Manufacturing Companies: An Application for Total Maintenance Costs Model

organizations in the industry with the superior quality and the wide range of product policies. It operates 80.000 tons with an annual production capacity and exports $40 \%$ of its total production to industrialized countries. The company serves as a major supplier of automotive companies such as Mercedes Benz, Man, Volvo, Scania, Audi, Porsche and Renault.

The failure analysis is made on the manufacturing steps of company such as surface preparation, cold forming, heat treatment, coating, sorting, packing. Statistical information about failures of previous year has been reached. In the firm the most failures (both in terms of number and duration) was found in the cold forming department. When the breakdowns that occurred in the cold forming department during the previous year were examined, the maximum number of buffer failures was observed, while the bolt failures caused the longest breakdown with a monthly average 1200 minutes stop. From the analyzed data, the company performed the fault analysis of the company and the maintenance costs model explained above. In the cold forming section, as a workstation was considered and one-month failure was investigated.

\section{Model 1 (CM and PM Costs)}

It is known that when the basic classification is made as corrective and preventive maintenance activities for maintenance activities, the operator plans preventive maintenance activities on Saturdays (out of working days). During the one-month review, " 3 " preventive maintenance activities were carried out on four Saturdays due to one overtime work day. During the days of preventive maintenance, there was no loss of production. Corrective maintenance activities to be performed with failures have been recorded in " 10 " records for one-month.

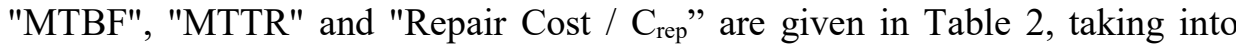
account the failures of the corrective maintenance.

Table 2: $M T B F, M T T R$ and $C_{\text {rep }}$ Values

\begin{tabular}{|c|c|c|c|c|c|c|c|c|c|c|c|c|}
\hline Variables & \multicolumn{10}{|c|}{ Values } & TOTAL & Average \\
\hline MTBF (hour) & 34 & 40 & 35 & 47 & 95 & 60 & 60 & 76 & 53 & 20 & 520 & $52 \mathrm{~h}$ \\
\hline $\begin{array}{c}\text { MTTR } \\
\text { (minute) } \\
\end{array}$ & 120 & 310 & 170 & 40 & 340 & 70 & 110 & 50 & 180 & 70 & 1460 & $146 \mathrm{~min}$ \\
\hline $\begin{array}{c}\text { Repair Cost / } \\
\text { Crep (TL) }\end{array}$ & 750 & 640 & 60 & 180 & 1050 & 110 & 210 & 170 & 340 & 70 & 3580 & $358 \mathrm{TL}$ \\
\hline$N_{C M}$ & \multicolumn{2}{|c|}{$N_{P M}$} & \multicolumn{2}{|c|}{$P R$} & $C_{l p}$ & & $L C$ & \multicolumn{2}{|c|}{$C_{r e p}$} & \multicolumn{2}{|r|}{$C_{r e s}$} & $T$ \\
\hline 10 times & \multicolumn{2}{|c|}{3 times } & \multicolumn{2}{|c|}{$\begin{array}{c}95-105 \\
\text { products }\end{array}$} & $0.090 \mathrm{TL}$ & & $\begin{array}{l}\text { Iinute: } \\
20 \mathrm{TL}\end{array}$ & \multicolumn{2}{|c|}{$358 \mathrm{TL}$} & \multicolumn{2}{|c|}{$750 \mathrm{TL}$} & $\begin{array}{l}272160 \\
\text { minutes }\end{array}$ \\
\hline
\end{tabular}

Total cost was found by adapting cost model to business data. In Model 1, the cost per unit time is calculated as CPUT. The implementation of Model 1 is given below. 


\section{Corrective Maintenance}

$$
\begin{aligned}
& E\left(C_{C M}\right)_{M 1}=M T T R_{C M} x\left[\begin{array}{lll}
P R & x C_{L P}+L C
\end{array}\right]+\overline{C_{r e p}} \\
& E\left(C_{C M}\right)_{M 1}=146 x\left[\begin{array}{lll}
100 & x & 0,090+0,20
\end{array}\right]+358 \\
& E\left(C_{C M}\right)_{M 1}=1701.2 T L
\end{aligned}
$$

\section{Preventive Maintenance}

$$
\begin{aligned}
& E\left(C_{P M}\right)_{M 1}=\text { MTTR }_{P M} \times\left[P R \times C_{L P}+L C\right]+\overline{C_{r e s}} \\
& E\left(C_{P M}\right)_{M 1}=\overline{C_{r e s}} \\
& E\left(C_{P M}\right)_{M 1}=750 T L
\end{aligned}
$$

\section{TOTAL MAINTENANCE COST:}

$$
\begin{aligned}
& E\left(C_{f}\right)_{M 1}=\left\{E\left[N_{C M}\right] \times E\left(C_{C M}\right)_{M 1}\right\}+\left\{\left[N_{P M}\right] \times E\left(C_{P M}\right)_{M 1}\right\} \\
& E\left(C_{f}\right)_{M 1}=\left\{\begin{array}{lll}
10 & x & 1701,2
\end{array}\right\}+\left\{\begin{array}{lll}
3 & x & 750
\end{array}\right\} \\
& E\left(C_{f}\right)_{M 1}=19262 \\
& T^{*}=\frac{T}{M T B F} \quad T^{*}=\frac{272160}{52 \times 60} \quad C P U T_{M 1}=\frac{19262}{87,23} \\
& C P U T_{M 1}=\frac{E\left(C_{f}\right)_{M 1}}{T^{*}} \\
& \text { CPUT }_{M 1}=220,81
\end{aligned}
$$

Model 2 (CM as $\mathrm{FC}_{1} \& F C_{2}$ and PM Costs)

There are two types of failures observed in the alternative maintenance cost model (Model 2) are identified in the $F C_{1}$ and $F C_{2}$ work schedule. The fault was immediately noticed when $F C_{1}$ was faulty. When $F C_{2}$ failed, the process went on unnoticed and the production was defective. There are 4 times $F C_{l}$ and 6 times $F C_{2}$. Corrective maintenance activities to be performed with failures have been recorded in 10 records for one-month. When the division of $\mathrm{CM}$ as $F C_{1}$ and $F C_{2}$ failure conditions, "MTBF", "MTTR", "Repair Cost / $\mathrm{C}_{\text {rep" }}$ and "faulty production time" are given in Table 3, taking into account the failures of the corrective maintenance. 
Equipment Maintenance Management in Manufacturing Companies: An Application for Total Maintenance Costs Model

Table 3: $F C_{1}$ and $F C_{2}$ Failure Conditions MTBF, MTTR, $C_{\text {rep }}$, Faulty Production Time Values

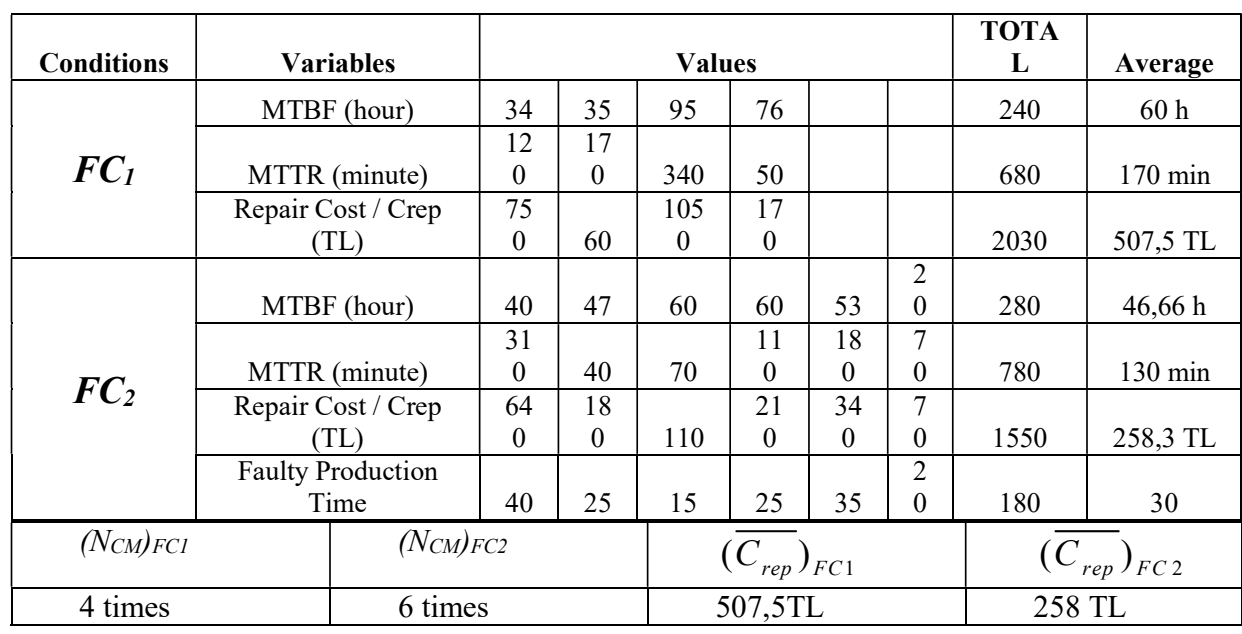

The total cost was found by adapting the alternative maintenance cost model to the business data. In Model 2, the cost per unit time is calculated as CPUT. The implementation of Model 2 is given below.

\section{Corrective Maintenance}

$$
\begin{aligned}
& E\left(C_{C M}\right)_{F C_{1}}=M_{T T R} \times\left[P R \times C_{L P}+L C\right]+\overline{C_{r e p}} \\
& E\left(C_{C M}\right)_{F C_{1}}=170 \times[100 \times 0,090+0,20]+507,5 \\
& E\left(C_{C M}\right)_{F C_{1}}=2071,5 T L \\
& E\left(C_{C M}\right)_{F C_{2}}=E\left(C_{r e j}\right)+M_{T T R} \times\left[P R \times C_{L P}+L C\right]+\overline{C_{r e p}} \\
& E\left(C_{r e j}\right)=C_{r e j} \times E\left(N_{\text {defect }}\right) \\
& E\left(N_{\text {defect }}\right)=\text { Scrap Recognation } x P R \\
& E\left(N_{\text {defect }}\right)=30 \times 100 \\
& E\left(N_{\text {defect }}\right)=3000 \\
& E\left(C_{C M}\right)_{F C_{2}}=0,09 \times 3000+130 \times[100 \times 0,09+0,20]+258,3 \\
& E\left(C_{C M}\right)_{F C_{2}}=1724,3 T L
\end{aligned}
$$

Preventive Maintenance

$$
\begin{aligned}
& E\left(C_{P M}\right)=M_{T T R_{P M}} \times\left[P R \times C_{L P}+L C\right]+\overline{C_{r e s}} \\
& E\left(C_{P M}\right)=\overline{C_{r e s}} \\
& E\left(C_{P M}\right)=750 \mathrm{TL}
\end{aligned}
$$




\section{TOTAL MAINTENANCE COST}

$$
\begin{aligned}
E\left(C_{f}\right)_{M 2}= & E\left(N_{C M}\right) x\left\{\left[E\left(C_{C M}\right)_{F C_{1}} \times P\left(F C_{1}\right)\right]+\left[E\left(C_{C M}\right)_{F C_{2}} \times P\left(F C_{2}\right)\right]\right\} \\
& +\left\{\left(N_{P M}\right) \times E\left(C_{P M}\right)\right\} \\
E\left(C_{f}\right)_{M 2}= & 10 x\{[2071,5 \times 0,4)]+[1724 x 0,6]\}+\{3 \times 750\} \\
E\left(C_{f}\right)_{M 2}= & 20880 T L \\
C_{C P U T}= & \frac{E\left(C_{f}\right)_{M 2}}{T^{*}} \\
\text { CPUT }_{M 2}= & \frac{20880}{87,23} \\
\text { CPUT }_{M 2}= & 239,367 T L
\end{aligned}
$$

The maintenance cost model (Model 1) considering CM and PM costs and the alternative maintenance cost model (Model 2) which CM differentiate to $F C_{l}$ and $F C_{2}$ were compared. For model 1, CPUT $\mathrm{m} 1$ was $220,81 \mathrm{TL} / \mathrm{min}$, while CPUT $_{\mathrm{m} 2}$ was $239,367 \mathrm{TL} / \mathrm{min}$. Considering the costs caused by the lack of maintenance and considering the loss of production as well as the scrap product costs, it is shown that the cost of maintenance 19TL more per minute, which is much less than the industry value and it is an important parameter to draw attention to the results of costs. This parameter will be the main basis for improving maintenance activities and removing lack of maintenance results.

\section{CONCLUSION}

Maintenance activities are the most basic supporting functions for businesses, but they are essential for the success of the production process. In this study, which assumes that it is useful for the enterprise to determine the damages caused by the poor maintenance while the maintenance is being carried out, the total maintenance costs for a company's failure schedule are addressed. In the maintenance cost model, which is examined from cost data, it is descriptive to draw attention once again to the fact that the maintenance of the high cost with the rejects. In addition to loss of production and labor loss, the costs of scrapping are also taken into consideration while carrying out the low cost for the enterprises and it is shown that the cost effect of 19 TL per minute will be an effect of approximately 5.000.000 TL per year. It is stated here that the maintenance activities are costly, but the lack of maintenance is more costly. It will also be possible for businesses to improve their maintenance systems and improve their maintenance performance, as well as to create a system that is far from being effective at lower costs and that is getting better. The study established on the failure analysis of a production operation and development of an alternative maintenance cost model to the traditional maintenance cost model, which was used to identify maintenance costs. The problem which is investigated 
Equipment Maintenance Management in Manufacturing Companies: An Application for Total Maintenance Costs Model

in this study is on a situation that businesses often meet but generally ignore. The failure should not be inherent in production but as an extraordinary situation caused by inadequate maintenance. Both the scope of the study and the scope of the academic work are potentially high in the field of application and further contributions to future maintenance cost model can be developed. A multidimensional model can be addressed by offering alternative cost estimates for the low-cost model. The main aim of these studies can be to reveal the total costs of maintenance operation in the most visible way and to improve the proposals.

\section{REFERENCES}

Ahlmann, H. (2002), "From Traditional Practice to The New Understanding: The Significance of The Life Cycle Profit Concept in The Management of Industrial Enterprises". In Maintenance Management \& Modelling Conference. International Foundation for Research in Maintenance.

Ahmad, R., and Kamaruddin, S. (2012), "An Overview of Time-Based and Condition-Based Maintenance in Industrial Application”. Computers \& Industrial Engineering, 63(1), pp.135-149.

Al-Najjar, B., and Algabroun, H. (2018), "A Model for Increasing Effectiveness and Profitability of Maintenance Performance: A Case Study". In Engineering Asset Management 2016 (pp. 1-12). Springer, Cham.

Alsyouf, I. (2006), "Methodology and Theory Measuring Maintenance Performance Using a Balanced Scorecard Approach", Journal of Quality in Maintenance Engineering, 12(2), pp.133-149.

Alsyouf, I. (2007), "The Role of Maintenance in Improving Companies' Productivity and Profitability". International Journal of Production Economics, 105(1), pp. 70-78.

Aspinwall, E., and Elgharib, M. (2013), "TPM Implementation in Large and Medium Size Organizations". Journal of Manufacturing Technology Management, 24(5), pp. 688-710.

Azizi, A. (2015), "Evaluation Improvement of Production Productivity Performance Using Statistical Process Control, Overall Equipment Efficiency, and Autonomous Maintenance". Procedia Manufacturing, 2, pp. 186-190.

Bevilacqua, M. and Braglia, M. (2000), "The Analytic Hierarchy Process Applied to Maintenance Strategy Selection”, Reliability Engineering \& System Safety, 70(1), pp. 71-83.

Carter, R.A., (2001), "Shovel Maintenance Gains from Improved Designs". Tools and Techniques. 106 (8), S7 (Elsevier Engineering Information).

Cho, D., and Parlar, M., (1991), "A Survey of Maintenance Models for MultiUnit Systems". European Journal of Operations Research, 51, pp. 1-23.

Coetzee, J.L. (2004), Maintenance, Trafford Publishing, Victoria. 
Dekker, R. (1996), "Applications of Maintenance Optimization Models: A Review and Analysis". Reliability Engineering and System Safety, 51, pp. 229-240.

Dekker, R., Wildeman, R.E., and Van Der Duyn Schouten, F.A., (1997), "Review of Multi-Component Models with Economic Dependence". Mathematical Methods of Operations Research, 45, pp. 411-435.

Gits, C.W., (1986), "On the Maintenance Concept for A Technical System: II. Literature Review" Maintenance Management International, 6, 181-196.

Jardine, A.K.S., and Buzacott, J.A., (1985), "Equipment Reliability and Maintenance". European Journal Operational Research, 19, pp.285-296.

Kulkarni, A., and Dabade, B. M. (2013), "Investigation of Human Aspect in Total Productive Maintenance (TPM): Literature Review . International Journal of Engineering Research and Development, 5(10), pp. 27-36.

Kutucuoglu, K., Hamali, J., Irani, Z., and Sharp, J., (2001), "A Framework for Managing Maintenance Using Performance Measurement Systems". International Journal of Operations and Production Management, 21 (1/2), pp. 173-194.

Maggard, B. and Rhyne, D. (1992), "Total Productive Maintenance: A Timely Integration of Production and Maintenance", Production and Inventory Management Journal, 33(4), pp. 6-10.

Mahadevan, B. (2015), Operations Management: Theory and Practice. Pearson Education India.

Maletic, D., Maletic, C., Al-Najjar, B. and Gomiscek, B. (2014), "The Role of Maintenance in Improving Company's Competitiveness and Profitability: A Case Study in A Textile Company", Journal of Manufacturing Technology Management, 25(4), pp. 441-456.

Pandey, D., Kulkarni, M. S., and Vrat, P. (2010), “A Model for Optimal Maintenance Interval Incorporating the Cost of Rejections in Manufacturing". Journal of Advances in Management Research. 7(2), pp. $219-232$.

Parida, A. and Kumar, U. (2006), "Maintenance performance measurement (MPM): issues and challenges", Journal of Quality in Maintenance Engineering, 12(3), pp. 239-51.

Pintelton, L.M., and Gelders, L., (1992), "Maintenance Management Decision Making”. European Journal of Operations Research, 58, pp. 301-317.

Salonen, A., and Deleryd, M. (2011), "Cost of Poor Maintenance". Journal of Quality in Maintenance Engineering. 17(1), pp. 63-73.

Sar1, E.B. (2018), Dünya Klasinda Üretim (WCM) (World Class Manufacturing, Ankara: Detay Yayıncılık.

Scarf, P.S., (1997), "On the Application of Mathematical Models to Maintenance”. European Journal of Operations Research, 63, 493-506. 
Equipment Maintenance Management in Manufacturing Companies: An Application for Total Maintenance Costs Model

Sherif, Y.S., and Smith, M.L., (1976), "Optimal Maintenance Models for Systems Subject to Failure-A Review". Naval Logistics Research Quarterly, 23, pp. 47-74.

Swanson, L., (2001), "Linking Maintenance Strategies to Performance", International Journal Production Economics, 70, pp. 237-244.

Thomas, L.C., (1986), "A Survey of Maintenance and Replacement Models for Maintainability and Reliability of Multi-Unit Systems". Reliability Engineering, 16, pp. 297-309.

Thun, J. H. (2006), "Maintaining Preventive Maintenance and Maintenance Prevention: Analyzing the Dynamic Implications of Total Productive Maintenance". System Dynamics Review: The Journal of the System Dynamics Society, 22(2), pp. 163-179.

Tsang, A.H.C., Jardine, A.K.S. and Kolodny, H. (1999), "Measuring Maintenance Performance: A Holistic Approach", Journal of Quality in Maintenance Engineering, 19(7), pp. 691-715.

Valdez-Flores, C., and Feldman, R.M., (1989), "A Survey of Preventive Maintenance Models for Stochastically Deteriorating Single-Unit Systems". Naval Logistics Research Quarterly, 36, 4.

Wang, H. (2002), "A Survey of Maintenance Policies of Deteriorating Systems". European Journal of Operational Research, 139, pp .469-489.

Wang, H. and Pham, H. (1996), "Imperfect Maintenance". European Journal of Operational Research, 94, pp. 425-438.

Willmott, P., and McCarthy, D. (2001), TPM-: A Route to World Class Performance. Newnes.

Wireman, T. (2004), Total Productive Maintenance. Industrial Press Inc.. 